\title{
進行性核上麻瘏と老人脳の大脳皮質における 老年性変化の出現頻度と形態の比較
}

\author{
岡山大学医学部神経精神医学教室（主任：大月三郎教授） \\ 佐々木健
}

(昭和55年 3 月 14 日受稿)
Key words : Progressive supranuclear palsy Neurofibrillary tangles in the cerebral cortex.

\section{ま え お き}

進行性核上麻㾝の主病変は基底核, 脳幹の神 経原線維変化である。本疾患の大脳皮質の原線 維変化の出現頻度については従来の報告はまち まちであるが，石野12)は 2 例の本疾患につき大 脳半球の Bodian 標本を用いて検索し, 大脳皮 質にも原線維変化が出現することを報告し，そ の頻度はおそらく正常老人䏚より多く，形態に も若千の違いがあることを報告した。しかしこ の原線維変化が本疾患に特有のものであり，老 人性変化によるものでないことを言うためには， 同じ部位，同じ染色法で老人脳を検索しそれと 比較することが必要である。一方進行性核上麻 㾴の脳幹における原線維変化は超微形態的にも 老人脳のものとは異なることが報告されている が，進行性核上麻㾇の大脳皮質における原線維 変化を電顕的に検索することはその出現数が少 ないため至難である。しかしもし進行性核上麻 㾝の大脳皮質の原線維変化の頻度や形態と老人 脳のそれとの間に差異が認められれば，進行性 核上麻㾝の原線維変化も老年変化ではなくて本 疾患に特異的なものであるという推測もある程 度可能になると思われる。この様な観点より私 は14例の老人脳を对照例として原線維変化の出 現頻度と形態の比較を行なった．同時にこの研 究は老人脳における老年性変化の頻度のコント ロールともなり得ることを目ざした。
対

象

表 1 に示す様に精神病院へ入院した70オから 91才までの老人14例と，62才と71才の進行性核 上麻痺の 2 例, 計 16 例である. 14例の老人の内 訳は男子 3 名, 女子11名であり，死亡時年令は $70 \sim 79$ 才 8 例, $80 \sim 89$ 才 4 例, 90 才以上 2 例, 平均年令は79才である. 全経過は 5 ヶ月より数 十年にわたるが，大部分は 1 - 5 年である。病 理診断は脳軟化症 7 例, 脳動脈硬化症 7 例であ る. 臨床診断は老年期精神病 6 例, 精神分裂病 1 例, 老年期痴呆症 7 例である. 病理診断と臨 床症状を对応させると, 老年期痴呆症と診断さ れた 7 例は臨床症状として失見当識, 記銘力障 害などの痴呆症状を示したが、これらの病理診 断は脳動脈硬化 2 例, 脳軟化 5 例であり,この 5 例は多発梗塞性痴呆である。老年期精神病と 診断された 6 例の主な臨床症状は幻聴, 被害妄 想, 独語などであり, 痴呆症状がないかあるい はごく較度のものであるが, 組織病理学的には 5 例が動脈硬化症, 1 例が脳軟化症と診断され た。また精神分裂病と診断された 1 例には脳軟 化がみられた。以上の14例中，夜間せん妄を含 む意識障害を呈したものが6例みられ，組織病 理学的に 4 例が脳動脈硬化症, 2 例が脳軟化症 であった。高血圧を示したものは 3 例であるが すべてが脳軟化例である。

万法

対照とした老人脳14例の各々の右あるいは左 
半球の前額断について前頭葉極の後方を通る部 (A)，視床忱を通る部(B)、頭頂葉を通る部(C)，後 頭部を通る部(D)，を切り出しパラフィンに包埋 し厚さ $5 \sim 6$ ミクロンに切り Bodian 染色をほ どこして大脳皮質の神経原線維変化に陥った神 経細胞，老人斑の実数を教え，同時に中脳，橋 脳，延随についても同様の検索を行った。一方 進行性核上麻㾇の 2 例についても同柡な方法で 検索を行ない大脳皮質における原線維変化と老 人斑の分布、形態を対照老人脳のそれと比較した。

結果

（I）老人脳における老年性変化の出現頻度 1. 神経原線維変化：(A)大脳皮質 原線維変化 は14例全例にみられた，各々の症例の 4 つの前
額断に出現した原線維変化の合計実数は，1～ 91個である，その内訳は $1 \sim 10$ 個が 4 例，11 50 個が 7 例， $51 \sim 91$ 個が 3 例となる。年令, 性 による出現数の差異はみられなかった。原線維 変化の分類については, $\mathrm{A} \sim \mathrm{D}$ の半球切片に出現し た実数の絵計は, A：1 個, B：202個, C：207個, $\mathrm{D} ： 5$ 個と切片 B，Cに集中している.更に詳し 〈分類すると, アンモン角, 海馬回, 海馬旁回 に312個，それを除く側頭葉に79個，前頭葉に 6 個，頭頂葉に 5 個，その他に 2 個みられ後頭葉 には認められなかった。その出現率もアンモン 角，海馬回，海馬芳回には全例に，それを除く 側頭葉には14例中12例に出現したが，前頭葉に は14例中 3 例に，頭頂葉には14例中 2 例に認め られたのみで，後頭葉に出現した症例はなかっ
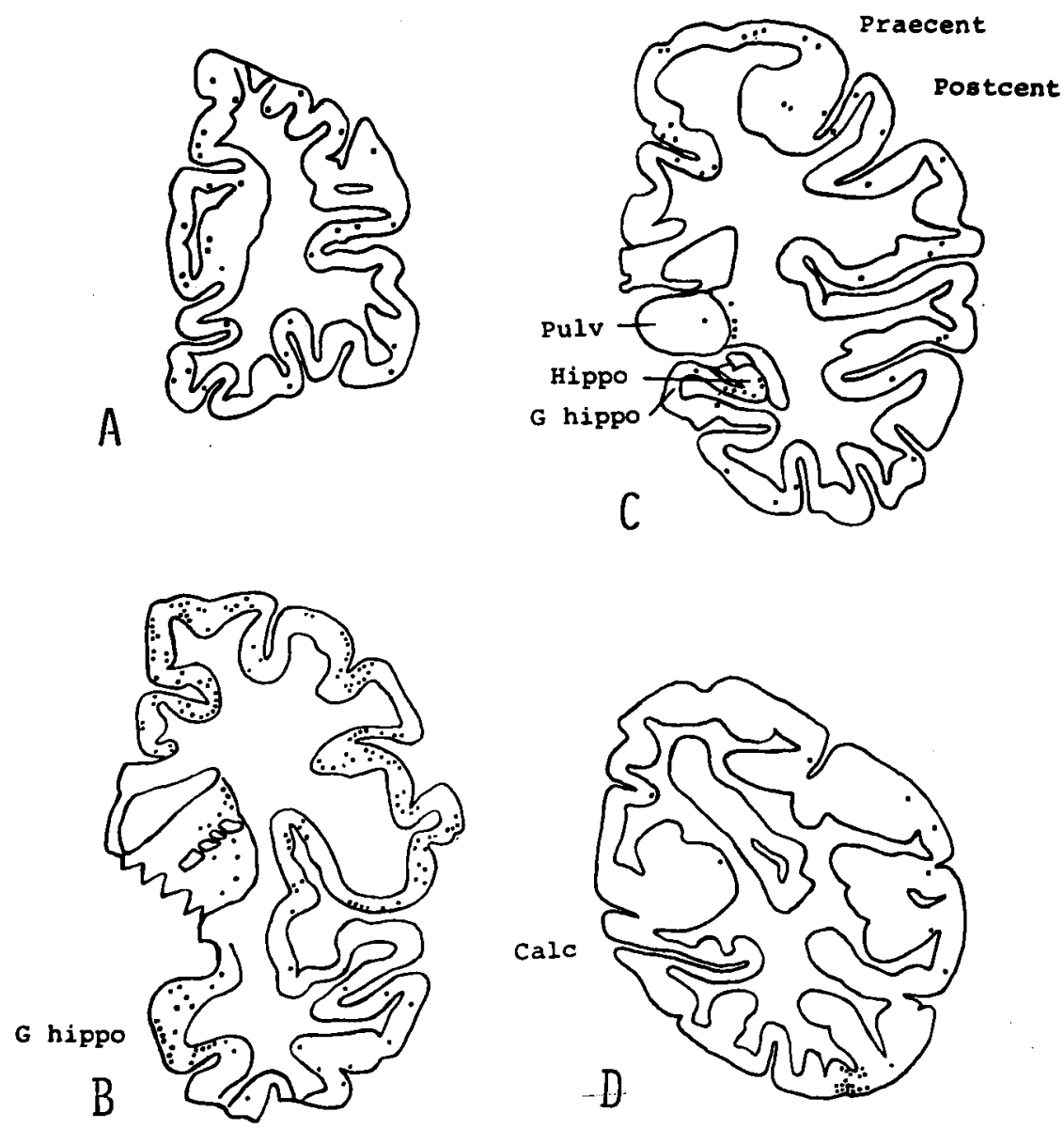

Fig. 1. Frequency of Alzheimer's neurofibrillary tangles in Case 15. One dot represents 1 neurohe with neurofibrillary tangles. 

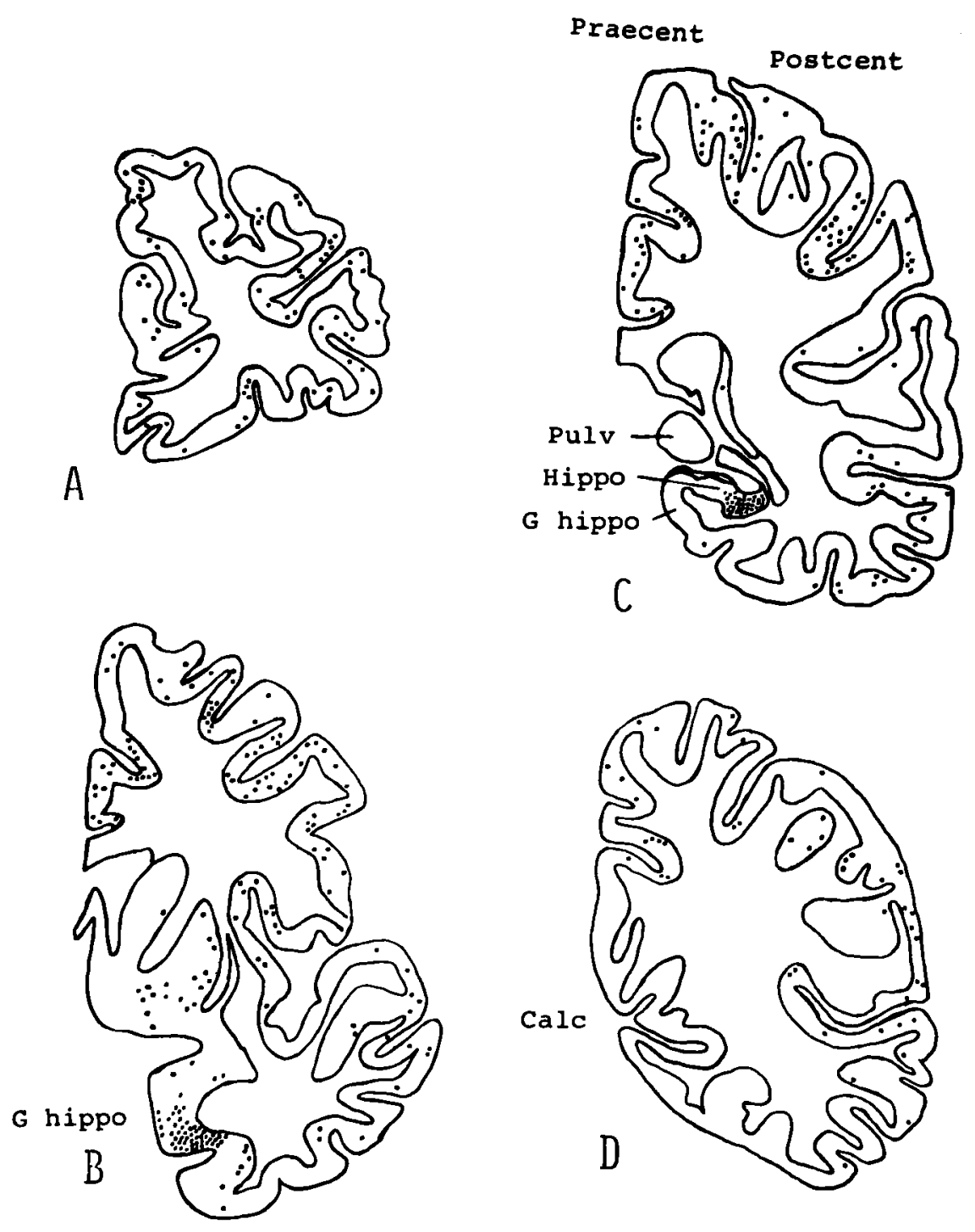

Fig. 2. Frequency of Alzheimer's neurofibrillary tangles in Case 16. One dot represents 1 neurone with neurofibrillary tangles.

た，各症例につきみるとアンモン角，海馬回， 海馬旁回のみに原線維変化がみられたもの2 例, アンモン角, 海馬回, 海馬旁回と側頭葉にのみ みられたもの5例となる。即ち原線維変化はア ンモン角, 海馬回，海馬旁回が第一の好発部位 であり，次いで側頭葉にも出現しやすいが，頭 頂葉, 前頭葉, 後頭葉には極めて稀である.(表 $2,3,4)$
(B)脳幹 原線維変化の出現は稀である。全くみ られないもの14例中 5 例であり，出現する症例 においても最高で 8 個と極めて少い.14例全例 の絵出現数は26個でその内訳は12個が N.dorsalis raphes, 5 個が青斑核に，2 個が N. centralis superior, 1 個が黒質に 6 個がその他とな る. 特にN. dorsalis raphesは14例中 7 例に出 現し最も頻度が高かった。（表 5 ） 


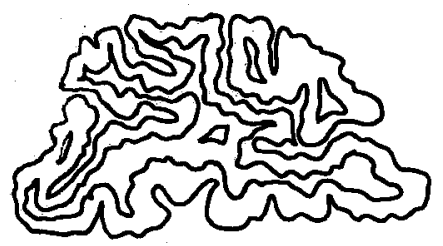

A

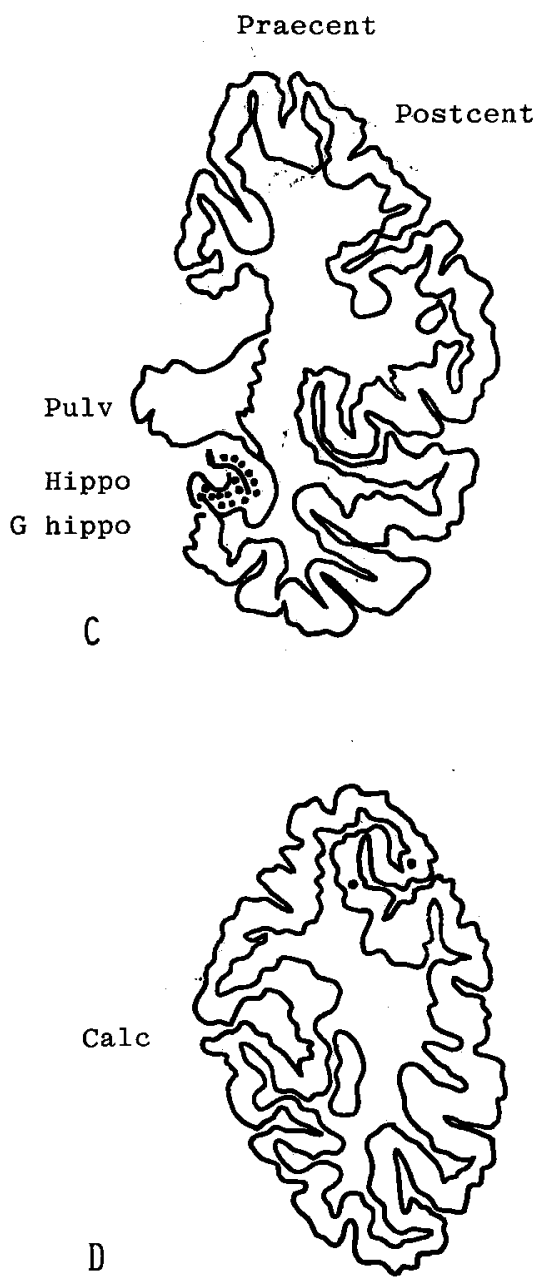

Fig. 3. Frequency of Alzheimer's neurofibrillary tangles in Case 2.

One dot represents 1 neurone with neurofibrillary tangles.

2.老人斑：14例中12例（86\%）に認められた。 各々の症例に認められた老人斑の実数は，1 546個であ。る。その内訳は老人斑のないもの 2 例， $1 \sim 10$ 個が 3 例，11 -100個が 5 例，101個以上 が 4 例となり，その出現には個体差が大きく， 年令との関連性はみられなかった，老人斑の分 布については14例の老人斑の数を総計するとA :332個, B : 392個, C : 393個, D : 291個と なり，原線維変化の様に切片 $\mathrm{B} ， \mathrm{C}$ 集中する ことなくほぼ均等に分布している．頭葉ごとに 分類すると, 前頭葉 663 個, 側頭葉402個, 頭頂 葉222個, 後頭葉42個, アンモン角, 海馬回, 海
馬旁回50個となるが、この実数の差は検索した 面積の差異によるものであり老人斑は各頭葉に 平均して広範に分布している，ただアンモン角， 海馬回, 海馬旁回にはやや少ない傾向がみられ た、頭葉別の出現率は14例中前頭葉は 9 例, 側 頭葉10例, 頭頂葉 9 例, 後頭葉 4 例, アンモン 角, 海馬回, 海馬旁回 7 例となる。即ち原線維 変化はアンモン角, 海馬回, 海馬旁回に好発し たが，老人斑は各頭葉に平均して広範に分布し ている。(表 6，7）

3. 原線維変化と老人斑との関保：原線維変化 の実数が多く 50 個以上の症例 $6,10,12 の 3$ 例 


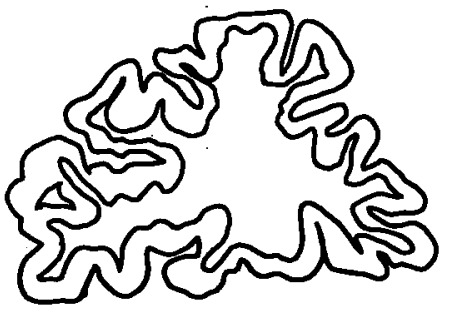

A

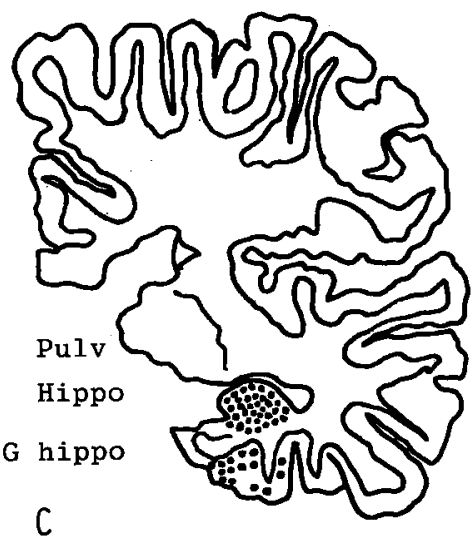

G hippo

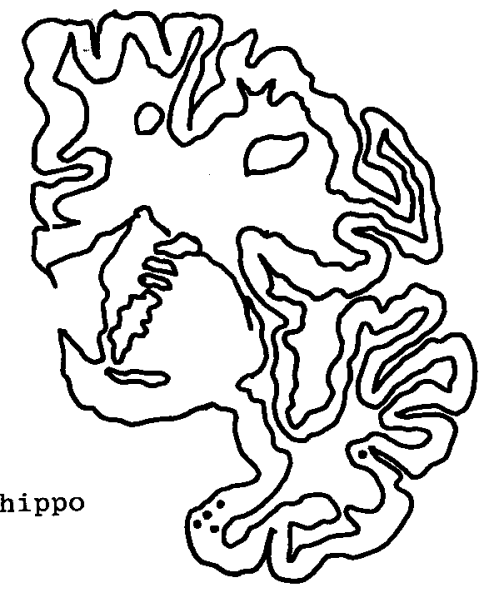

D

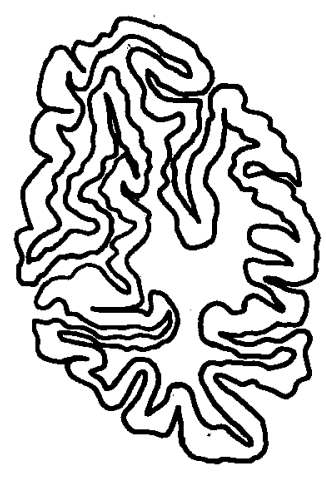

Fig. 4. Frepuency of Alzheimer's neurofibrillary tangles in Case 6. One dot represents 1 neurone with neurofibrillary tangles.

\begin{tabular}{|c|c|c|c|c|c|c|}
\hline 症例番号 & 性 & 年䁖 & 半球切片 $\mathrm{A}$ & 半球切片 B & 半球切片 C & 半球切片 D \\
\hline 1 & $F$ & 91 & - & 4 & 18 & - \\
\hline 2 & $\mathbf{F}$ & 90 & - & 18 & 16 & 2 \\
\hline 3 & $\mathrm{~F}$ & 82 & - & 3 & 38 & 1 \\
\hline 4 & $\mathrm{~F}$ & 82 & - & 1 & 11 & - \\
\hline 5 & $F$ & 82 & - & 23 & 3 & 1 \\
\hline 6 & $\mathrm{~F}$ & 80 & - & 5 & 48 & - \\
\hline 7 & $\mathrm{~F}$ & 79 & - & 1 & - & - \\
\hline 8 & $\mathbf{F}$ & 79 & - & 3 & 6 & 1 \\
\hline 9 & $\mathbf{M}$ & 79 & - & 15 & - & - \\
\hline 10 & $M$ & 76 & - & 74 & 17 & - \\
\hline 11 & $\mathbf{F}$ & 74 & - & 7 & 24 & - \\
\hline 12 & $\mathbf{F}$ & 73 & 1 & 37 & 20 & - \\
\hline 13 & $\mathbf{F}$ & 70 & - & 5 & 3 & - \\
\hline 14 & $\mathbf{M}$ & 70 & - & 4 & 3 & - \\
\hline $\begin{array}{ll}\mathrm{P} & 15 \\
\mathrm{~S} & \end{array}$ & $\mathbf{M}$ & 71 & 30 & 155 & 38 & 26 \\
\hline $\begin{array}{ll}\mathrm{P} & 16 \\
\end{array}$ & $\mathrm{M}$ & 62 & 59 & 185 & 128 & $\begin{array}{l}4 \\
45\end{array}$ \\
\hline
\end{tabular}

につき老人斑の出現数を みると，48，0，1 個で ありこれらの症例では老 人斑の出現数は中等度の もの 1 例，軽度あるいは 存在しないもの 2 例とな る。 又逆に老人斑が多く 101 個以上の症例 2, 4, 7, 13の4 例については原線 維変化の数は $38,12,1$, 8 個であり，少数または 中等度となる。即ち両者 はその出現数において解 離傾向にあることがかか る.（表 8）その出現部 位も原線維変化はアンモ 
表 3 進行性核上麻㾝 (PSP) と老人脳の半球切片 B における部位別の原線維変化の出現数

\begin{tabular}{|c|c|c|c|c|c|}
\hline 症例番号 & 性 & 年齢 & 切片 Bの海馬領域 & その他の側頭葉 & 前頭葉 \\
\hline 1 & $F$ & 91 & - & 2 & 2 \\
\hline 2 & $\mathrm{~F}$ & 90 & - & 12 & - \\
\hline 3 & $F$ & 82 & - & 3 & - \\
\hline 4 & $F$ & 82 & - & 1 & - \\
\hline 5 & $\mathrm{~F}$ & 82 & 21 & 2 & - \\
\hline 6 & $\mathrm{~F}$ & 80 & 4 & 1 & - \\
\hline 7 & $\mathrm{~F}$ & 79 & 1 & - & - \\
\hline 8 & $\mathrm{~F}$ & 79 & 2 & 1 & - \\
\hline 9 & M & 79 & 14 & 1 & - \\
\hline 10 & M & 76 & 51 & 23 & - \\
\hline 11 & $\mathrm{~F}$ & 74 & 4 & 3 & - \\
\hline 12 & $\mathrm{~F}$ & 73 & 16 & 18 & 1 \\
\hline 13 & $\mathrm{~F}$ & 70 & 1 & 1 & 2 \\
\hline 14 & $\mathbf{M}$ & 70 & 4 & - & - \\
\hline $\begin{array}{ll}\mathrm{P} & 15 \\
\mathrm{~S} & 15\end{array}$ & $\mathrm{M}$ & 71 & 23 & 11 & 121 \\
\hline $\mathrm{P} \quad 16$ & $\mathbf{M}$ & 62 & 61 & 19 & 105 \\
\hline
\end{tabular}

表 4 進行性核上麻㾝 (PSP) と老人脳の半切片 C における部位別の原線維変化の出現数

\begin{tabular}{|c|c|c|c|c|c|c|}
\hline 症例番号 & 性 & 年龄 & 切片 Cの海馬領域 & その他の側頭葉 & 頭頂葉 & 前頭葉 \\
\hline 1 & $F$ & 91 & 17 & - & 1 & - \\
\hline 2 & $\mathbf{F}$ & 90 & 16 & - & - & - \\
\hline 3 & $F$ & 82 & 33 & 4 & 1 & - \\
\hline 4 & $\mathrm{~F}$ & 82 & 11 & - & - & - \\
\hline 5 & $\mathrm{~F}$ & 82 & 3 & - & - & - \\
\hline 6 & $\mathrm{~F}$ & 80 & 48 & - & - & - \\
\hline 7 & $F$ & 79 & - & - & - & - \\
\hline 8 & $\mathrm{~F}$ & 79 & 5 & 1 & - & - \\
\hline$\theta$ & M & 79 & - & - & - & - \\
\hline 10 & $\mathbf{M}$ & 76 & 15 & 2 & - & - \\
\hline 11 & $\mathrm{~F}$ & 74 & 23 & 1 & - & - \\
\hline 12 & $F$ & 73 & 19 & 1 & - & - \\
\hline 13 & $\mathrm{~F}$ & 70 & 1 & 2 & - & - \\
\hline 14 & M & 70 & 3 & - & - & - \\
\hline $\begin{array}{ll}\mathrm{P} & 15\end{array}$ & $\mathrm{M}$ & 71 & 8 & 5 & 9 & 16 \\
\hline $\begin{array}{ll}\mathrm{S} & \\
\mathrm{P} & 16 \\
\end{array}$ & $\mathrm{M}$ & 62 & 31 & 18 & 44 & 35 \\
\hline
\end{tabular}
った。

6)のみであり, 症例数が少な く痴呆との関係は比較できなか

（II）老人脳における老年性変 化の形態

1. 原線維変化: Bodian 染色 で茶褐色や茶色に染まる太い線 維がからまりあって細胞体や核 がわからないものや, 神経原線 維が束になり重なりあって細胞 体の形が保たれず三角形を呈し ている細胞, 細胞体が消失し神 経原線維の束がもつれあって系 だま状を呈するものがみられた。 (図1A)

2. 老人斑：アミロイドよりな る芯をもたない小型のものが多 くを占め(図 1B，1C), 芯をもつ 大型で成熟したものは少 なかった。(図 IC)

（III）進行性核上麻皁 と老人脳における老年性 変化の比較

進行性核上麻痷の 2 例 （症例 15 , 症例16)につき 同様な方法で検索を行い， 原線維変化，老人斑の分 布, 形態を老人脳14例(症 例 1 ～14）と比較した。 1. 原線維変化の分布と 出現数：進行性核上麻瘦 の2例についてみると原 線維変化の出現数では差 があるが分布には本質的 な差がみられない，進行 性核上麻疸の症例16では

ン角，海馬回，海馬旁回が好発部位であるのに 対して，老人斑にはこの様な傾向は認められず， 分布においても解離している。（表 7)

4. 原線維変化, 老人斑と痴呆との関係：臨床 的に老年期窥呆症と診断された 7 例のうち 5 例 (症例 $3,7,10,11,12$ ) は病理診断で脳軟 化症であり, 脳軟化のないものは 2 例（症例 2 ,
海馬, 海馬回に多数出現しているが, 症例15で はこの部に少数を認めるだけである。しかし2 例とも前頭葉ではかなり多数の原線維変化の出 現をみており, 頭頂葉では症例 15 は症例 16 と比 へてて少ないものの稀とは言えない程度に出現す る。この様な進行性核上麻㾇における分布を， 対照とした老人脳14例の分布と比較すると次の 
表 5 老人脳の脳幹における神経原線維変化の出現数

\begin{tabular}{|c|c|c|c|c|c|c|c|}
\hline 症例番号 & 性 & 年歯 & $\begin{array}{l}\text { N. dorsalis } \\
\text { raphes }\end{array}$ & $\begin{array}{c}\text { N.cen ralis } \\
\text { superior }\end{array}$ & 青斑核 & 黒 質 & その他 \\
\hline 1 & $F$ & 91 & 3 & - & - & - & 5 \\
\hline 2 & $\mathbf{F}$ & 90 & - & - & - & - & - \\
\hline 3 & $\mathbf{F}$ & 82 & 1 & - & - & - & - \\
\hline 4 & $\mathbf{F}$ & 82 & 1 & - & - & - & - \\
\hline 5 & $\mathrm{~F}$ & 82 & - & - & - & - & - \\
\hline 6 & $\mathbf{F}$ & 80 & - & - & 1 & - & - \\
\hline 7 & $\mathrm{~F}$ & 79 & - & - & - & - & - \\
\hline 8 & $\mathrm{~F}$ & 79 & - & - & - & - & - \\
\hline 9 & $\mathbf{M}$ & 79 & - & - & - & - & - \\
\hline 10 & $\mathbf{M}$ & 76 & - & - & 3 & 1 & - \\
\hline 11 & $\mathrm{~F}$ & 74 & 3 & - & 1 & - & - \\
\hline 12 & $\mathbf{F}$ & 73 & 2 & 2 & 0 & 0 & 1 \\
\hline 13 & $\mathbf{F}$ & 70 & 1 & - & - & - & - \\
\hline 14 & $\mathbf{M}$ & 70 & 1 & - & - & - & - \\
\hline
\end{tabular}

表 6 進行性核上麻㾇（PSP）と老人脳の老人斑の出現数

\begin{tabular}{|c|c|c|c|c|c|c|}
\hline 症例番号 & 性 & 年龄 & 半球切片 $\mathrm{A}$ & 半球切片 $\mathrm{B}$ & 半球切片 $\mathrm{C}$ & 半球切片 D \\
\hline 1 & $\mathbf{F}$ & 91 & 1 & - & 10 & 2 \\
\hline 2 & $\mathbf{F}$ & 90 & 78 & 64 & $1_{26}$ & 77 \\
\hline 3 & $\mathbf{F}$ & 82 & - & - & - & - \\
\hline 4 & $\mathbf{F}$ & 82 & 191 & 217 & 88 & 50 \\
\hline 5 & $\mathbf{F}$ & 82 & - & - & 10 & 26 \\
\hline 6 & $F$ & 80 & 36 & - & 11 & 1 \\
\hline 7 & $\mathbf{F}$ & 79 & 11 & 47 & 55 & 58 \\
\hline 8 & $\mathbf{F}$ & 79 & - & 1 & - & 2 \\
\hline 9 & $\mathbf{M}$ & 79 & - & 14 & 18 & 1 \\
\hline 10 & $\mathbf{M}$ & 76 & - & - & - & - \\
\hline 11 & $\mathbf{F}$ & 74 & 4 & 2 & - & - \\
\hline 12 & $\mathbf{F}$ & 73 & - & 1 & - & - \\
\hline 13 & $\mathbf{F}$ & 70 & 2 & 46 & 50 & 45 \\
\hline 14 & M & 70 & 9 & - & 25 & 29 \\
\hline$\underset{S}{P} 15$ & $M$ & 71 & - & - & - & - \\
\hline P 16 & $\mathbf{M}$ & 62 & - & - & - & - \\
\hline
\end{tabular}

側頭葉には対照群14例中 3 例に20個以上の出現を みておりこれらと比較 すると進行性核上麻㵒の 2 例においてその出現数 が特に多いとはいえない. 切片Cのアンモン角, 海 馬での出現数は進行性核 上麻痷 2 症例の間に差が あり，症例16ではこの部 位に原線維変化が多いの， に対して，症例15では少 数である.対照群ではこ の部位が一番の好発部位 で全例に出現をみている が，その出現数が多いも のではこの部位に集中す る傾向にあるが, 出現数 が少いものでは集中傾向 はなく，この部位に関し ては進行性核上麻瘏と対 照群で差異がない，一方， 中心前回, 中心後回にお ける出現数は対照群では 中心後回に 2 例に各 1 個 づつみたのに対し，進行 性核上麻痷の 2 例ではそ れと比べてはるかに多い. またこの切片での側頭葉 における出現数は進行性 核上麻痷の 2 例ではいず れも10個以上の出現をみ ているが, 对照群でも 14 例中 6 例に最高 4 個の出 現をみており，進行性核

様になる．切片Aでは対照群14例中 1 例に 1 個 の原線維変化をみたのみに対し, 進行性核上麻 盘の 2 例には対照群と比較すると明らかに多く 出現している. 切片Bの前頭葉では对照群14例 中 3 例に出現したのみであり，しかもそのうち 2 例では 2 個， 1 例では 1 個の出現に過ぎない. 一方進行性核上麻瘏の 2 例でははるかに高頻度 に出現している。しかしこの切片での海馬回,
上麻痷の方に多く出現しているが明らかに多い とは言い難い。切片Dでは両群ともに出現数は 少ないが，対照群では14例中 4 例に出現したの みで，その数も 4 例中 3 例が各々 1 個づつ, 1 例が 2 個という頻度と比べれば，進行性核上麻 瘏の 2 例では明らかに多い（表 2-4）

2. 原線維変化の形態：進行性核上麻疸では, Bodian 染色で茶褐色に染るものが 1 2 割で, 
表 7 進行性核上麻軯 (PSP) と老人脳における老人斑の頭葉別出現数

\begin{tabular}{|c|c|c|c|c|c|c|c|c|}
\hline 症例番号 & 性 & 年齢 & 前頭葉 & 海馬領域 & 側頭葉 & 頍頂葉 & 後頭葉 & その例 \\
\hline 1 & $F$ & 91 & 4 & 2 & - & 6 & - & 1 \\
\hline 2 & $F$ & 90 & 140 & 5 & 91 & 75 & 21 & 13 \\
\hline 3 & $F$ & 82 & - & - & - & - & - & - \\
\hline 4 & $\mathbf{F}$ & 82 & 357 & 26 & 130 & 32 & 1 & - \\
\hline 5 & $\mathrm{~F}$ & 82 & - & - & 33 & 3 & - & - \\
\hline 6 & $\mathrm{~F}$ & 80 & 37 & - & 9 & - & 1 & 1 \\
\hline 7 & $\mathrm{~F}$ & 79 & 57 & 14 & 27 & 53 & 19 & 1 \\
\hline 8 & $\mathbf{F}$ & 79 & - & - & 2 & 1 & - & - \\
\hline 9 & M & 79 & 2 & - & 27 & 4 & - & - \\
\hline 10 & $\mathrm{M}$ & 76 & - & - & - & - & - & - \\
\hline 11 & $\mathrm{~F}$ & 74 & 4 & - & 2 & - & - & - \\
\hline 12 & $F$ & 73 & - & 1 & - & - & - & - \\
\hline 13 & $F$ & 70 & 41 & 1 & 61 & 27 & - & 13 \\
\hline 14 & M & 70 & 21 & 1 & 10 & 21 & - & - \\
\hline $\begin{array}{ll}\mathrm{P} & 15 \\
\mathrm{~S}\end{array}$ & $\mathrm{M}$ & 71 & - & - & - & - & - & - \\
\hline $\mathrm{P} \quad 16$ & M & 62 & - & - & - & - & - & - \\
\hline
\end{tabular}

ものと網目状のものが 混在するもの（図 2L, 2M)などが多い.一方 普通の原線維変化はご く少数認められただけ である(図 $3 \mathrm{~A}-3 \mathrm{C}$ )。 これに対して主として 海馬域には対照老人脳 にみられた様な原線維 変化, 即ち普通の茶褐 色から茶色に染まる太 い原線維がもつれあっ て細胞体も核もわから ないもの，原線維が束 になって重なりあい細 胞体の形が保たれず三 角形になっているもの も多くみられた（図 3D，3E）また前述した Bodian 染色で濃染する 特徴をもった原線維変化は橋核の神経細胞にもみ られ，大脳皮質にみられるものと同様に核や細胞体 の形はよく保たれた網目状, 紐状の原線維変化を 認め（图 $3 \mathrm{~F}-3 \mathrm{I}$ )，大脳皮質にみられたものと 近似していた。

3. 老人斑：進行性核上麻㾝では 2 例とも老人 斑は出現しておらず, 对照老人脳の出現頻度, 出現量と比較してきわだった対照をみせている。 (表 6, 7)

\section{考察}

老人脳における神経原線維変化や老人斑など の老年性変化の頻度, 分布は表 9 に示した様に Gellerstedt ${ }^{6)}$ 以来多くの研究があり，その変化 と痴呆との関係についても, Dayan ${ }^{4) 5)}$, Bles$\operatorname{sed}^{11}$, Tomlinson ${ }^{24)}$, 森松 ${ }^{17)} ら の$ 研究がある. 従 来の研究がその検索部位を海馬領域にかぎって いたり，全脳を対象とした研究においても各頭 葉の一部分をとり出して検索しているのに対し， 私は大脳半球切片で検索を行い, 老人脳におけ る老年性変化の頻度のコントロールともなり得 ることをめざした。先ず老人脳14例について老 年性変化の考察を行う.

1. 老人脳における原線維変化と老人斑の出現 


\section{佐々木健論文附図}

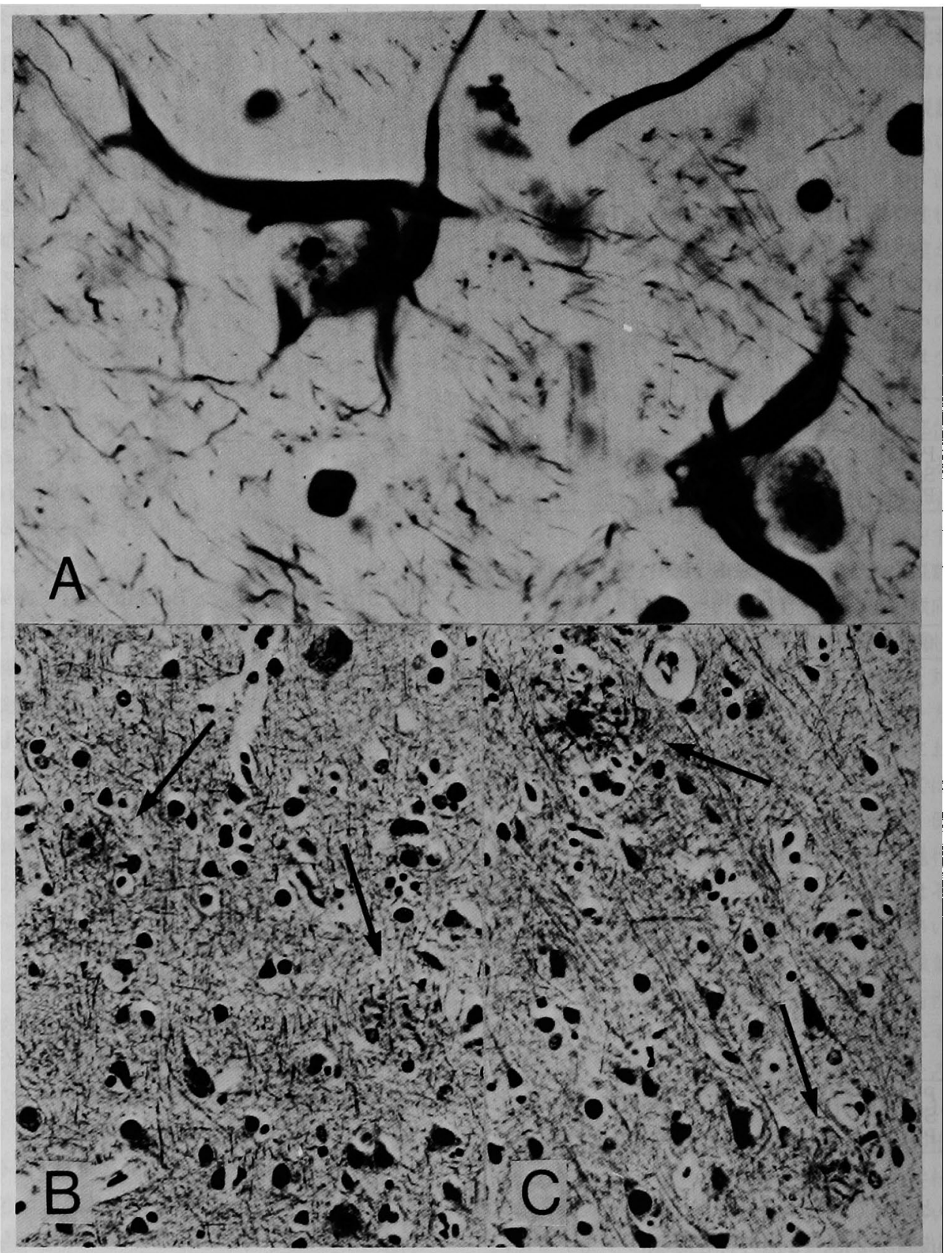

図 1 对照老人脑，Bodian染色 A：症例(22，海馬の原線維変化 $(\times 1000) ； \mathrm{~B}$ : 症例(4)， 前頭葉の 2 コの老人斑( $\uparrow)(\times 200) ; C$ : 症例(2)，前頭葉の 2 コの老人斑 $(\uparrow)(\times 200)$ 上部の ものは核を有したもの. 
佐々木健論文附図

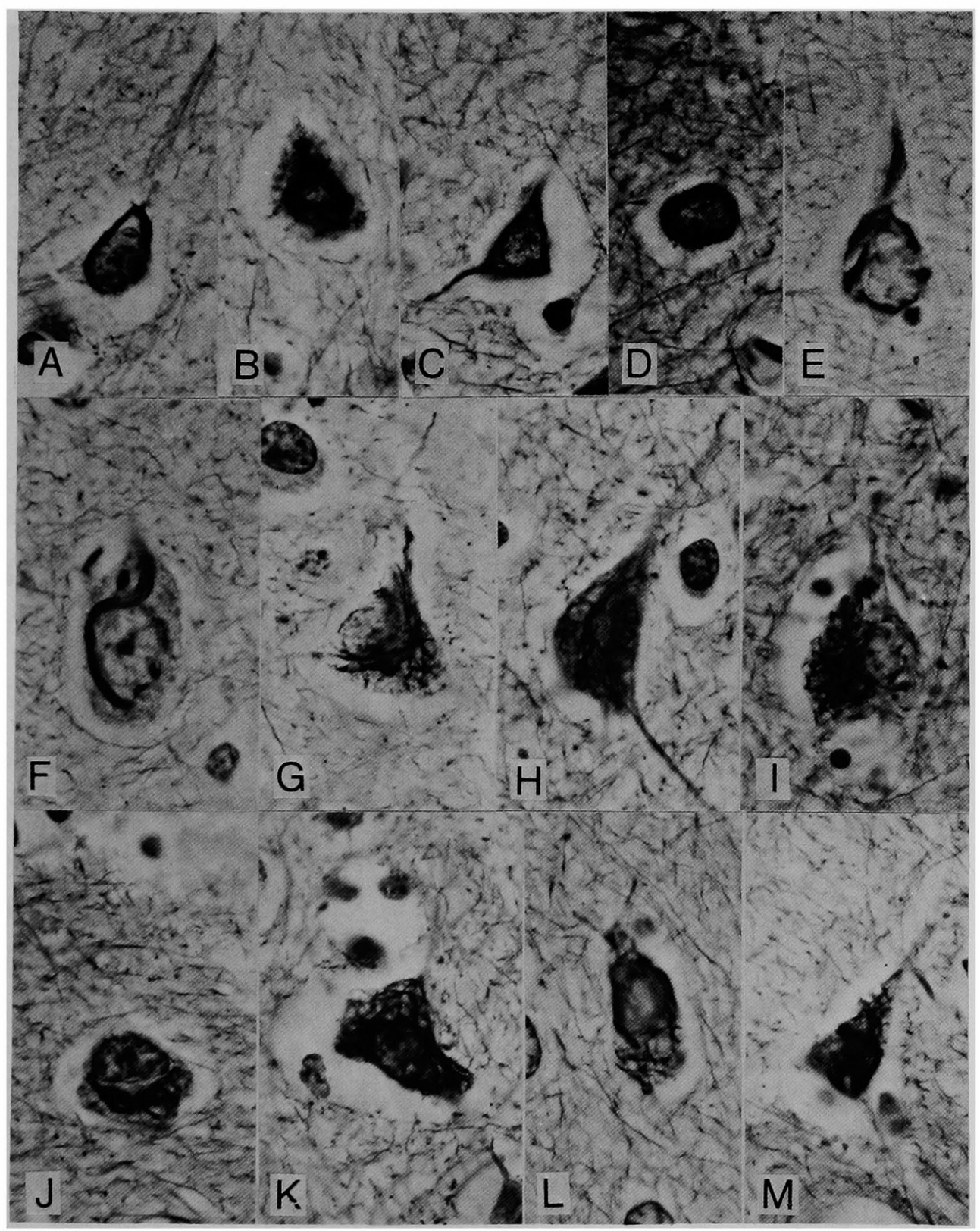

図 2 進行性核上麻㾴 2 例の原線維変化, Bodian 染色 $(\times 1000), \mathrm{A}$ : 症例15. 前頭葉;

$B ：$ 症例 15 , 前頭葉；C：症例15, 頭頂葉； D : 症例16, 側頭葉； $E ：$ 症例 15 , 側頭葉 ; $F:$ 症例 15 , 側頭葉 ; $G:$ 症例 16 , 前頭葉; $H:$ 症例 16 , 前頭葉; I : 症例 16 , 側 頭葉； $\mathrm{J}$ : 症例 16 , 前頭葉； $\mathrm{K}$ ：症例15, 海馬； $\mathrm{L}$ ：症例 15 , 側頭葉； $\mathrm{M}$ ：症例 15 , 前頭葉 


\section{佐々木健論文附図}

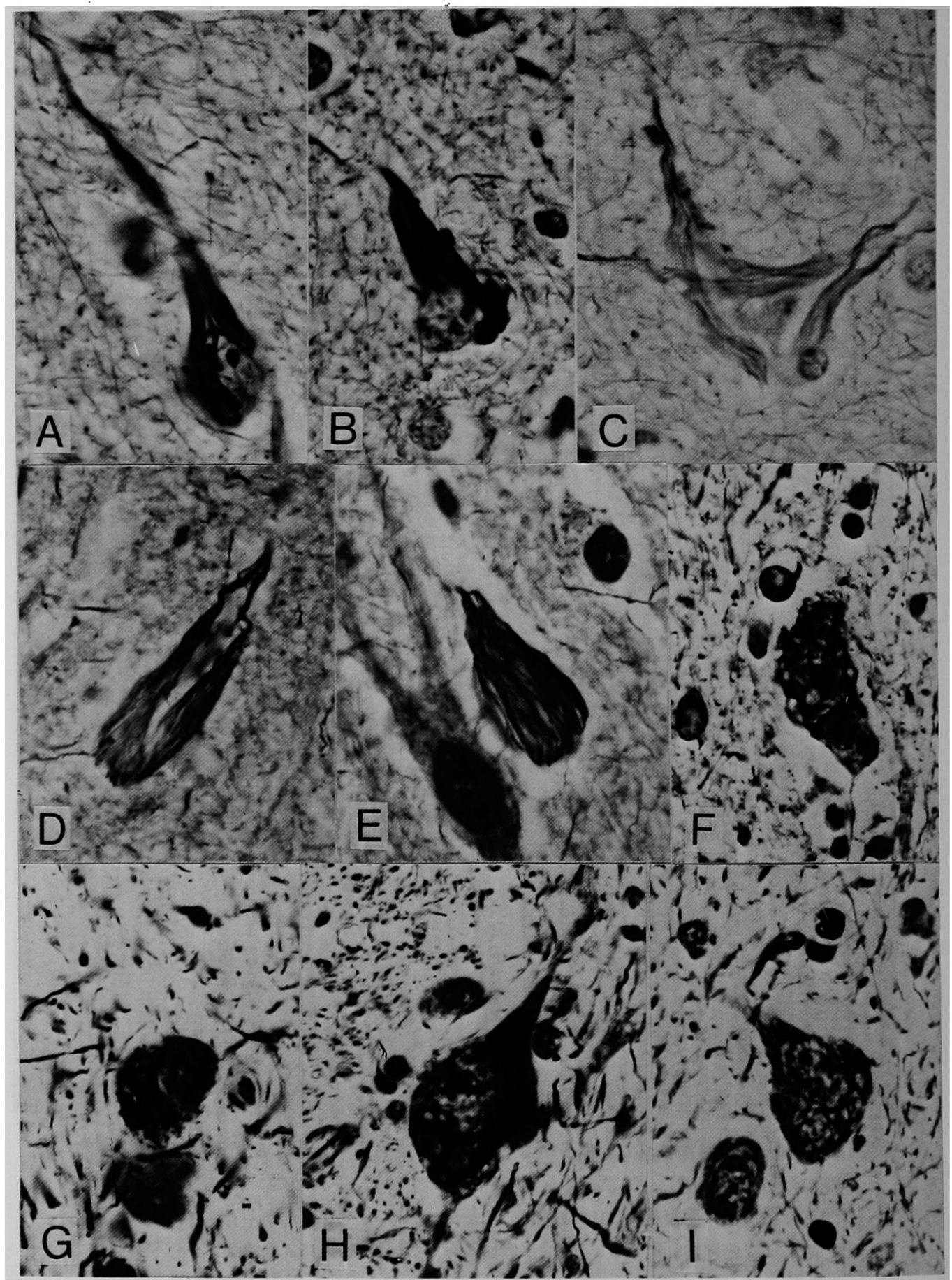

図 3 進行性核上麻㾝 2 例の原線維変化，Bodian 染色 $(\times 1000), A$ : 症例15，頭頂葉； $B$ : 症例15，頭頂葉；C：症例15，側頭葉； D：症例16，海馬；E：症例15，海馬； $\mathrm{F}-\mathrm{H}$ : 症例 16 , 橋核; I : 症例 15 , 橋核 


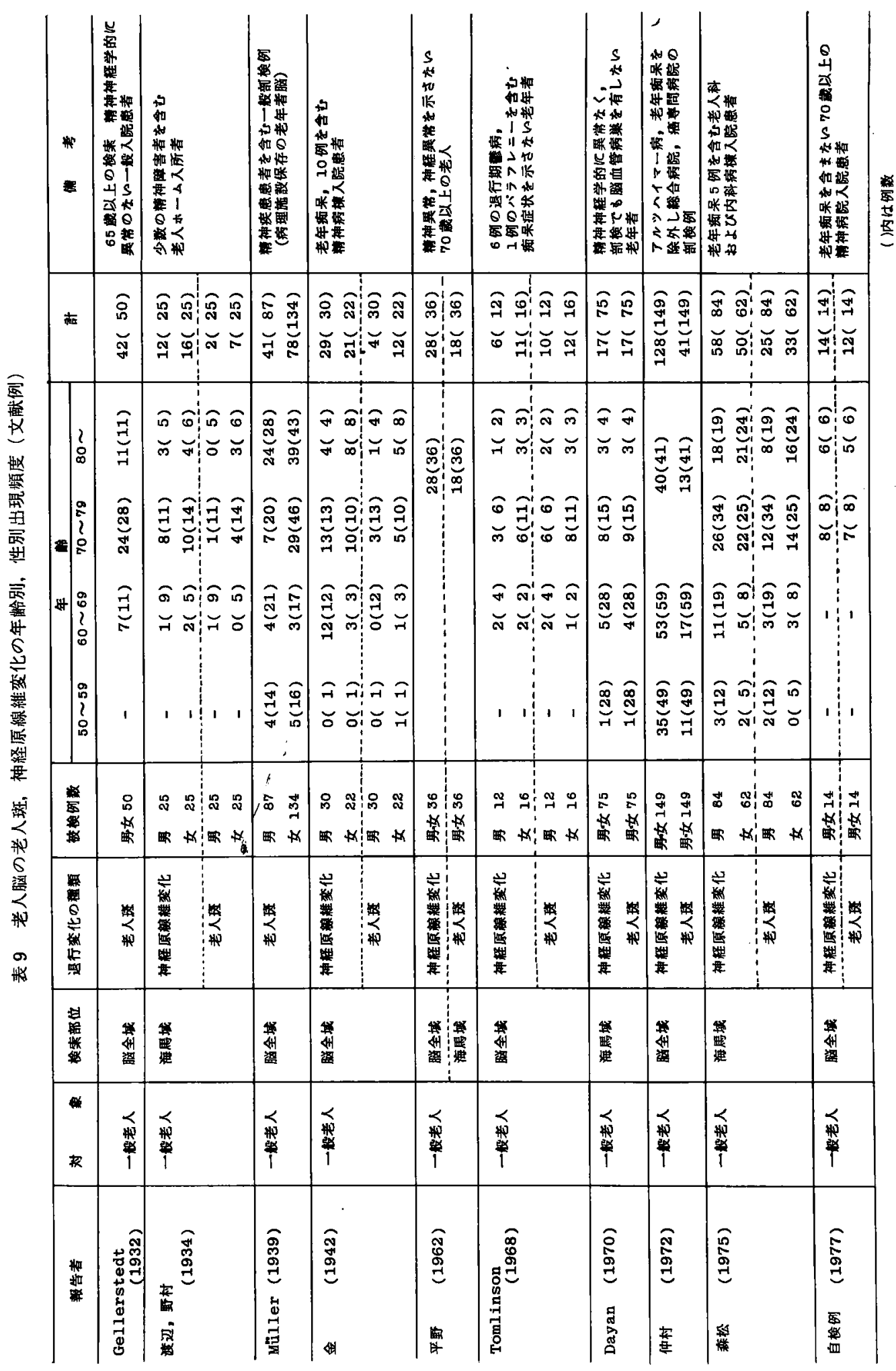


頻度と分布：従来の研究では原線維変化の頻度 や分布は前述した樣に検索範团や対象が各々の 研究でまちまちで，いちがいに比較する訳には いかないが，70才以上の老年者ではその頻度は， 金 ${ }^{13)}(100 \%)$ ，仲村 ${ }^{191}(97 \%)$, 森松 ${ }^{17)}(85 \%)$ ， 平野7) $(78 \%)$ ，渡辺，野村 ${ }^{26)}(69 \%)$, Tomlin$\operatorname{son}^{24)}(59 \%), \operatorname{Dayan}^{4)}(58 \%)$ で，諸家の報告 にはかなりのへだたりがみられる。この研究で は14例全例にみられ，金，仲村らの結果に近い。 一方その分布は一般老人では海馬およびその周 辺に最も出現しやすいことは古くからよく知ら れてお、り，海馬域以外の他の皮質は出現頻度， 出現量ともに著しく劣ることは諸家の一致する ところである( 金 ${ }^{13)}$, 渡辺, 野村 ${ }^{26)}$, 猪瀨 ${ }^{9}$, 平野 ${ }^{71}$ ，仲村 ${ }^{191}$, Tomlinson $\left.{ }^{241}\right)$. この研究でも アンモン角，海馬回，海馬旁回には全例におい て出現しており，その出現量も最も多く，次い でこの部位を除く側頭葉に14例中12例みられた が出現量は $1 / 4$ とはるかに少なく，前頭葉では 14 例中 3 例にみられ，その量も各例 2 個づつ，頭 頂葉ではごく少数を 4 例に認めたのみで, 後頭 葉には認めなかった，即方前頭葉，頭頂葉，後 頭葉には極めて稀であるという結論になり諸家 の報告と分布の面では一致する。

老人斑は14例中12例にみられ，その出現頻度 は86\%となり Gellerstedt ${ }^{6)}(89.7 \%)$, Tomlin. $\operatorname{son}^{24)}(86 \%)$, Müller ${ }^{18)}(72.3 \%)$, Dayan ${ }^{4)}(63$ \%)に近いが, 平野” $(50 \%)$, 森松17 $(49 \%)$, 金 $^{13)}(40 \%)$ ，仲村 ${ }^{19)}(32 \%)$ ，渡辺，野村 ${ }^{26)}(22.2$ \%)と比較するとその頻度は高い。私の検索で は老人斑は前頭葉から後頭葉に致るまで広笵に 分布し，前頭葉，側頭葉に比較的多いが，原線 維変化が集中しているアンモン角，海馬回，海 馬旁回には比較的少なく，これが諸家の出現頻 度の差の要因の 1 つになっていると思われる。 つまり全脳を調べな諸家の報告ではその出現頻 度が高く(Gellerstedt ${ }^{6)}$, Tomlinson ${ }^{24)}$, Müller 18)），海馬域のみ調へたものでは頻度が低い傾向

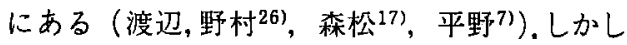
金 ${ }^{13)}$ ，仲村 ${ }^{19}$ は全腷を検索したが低い頻度でし かみられなかったと報告している，私の研究で 老人斑の出現の仕方をみると, 年令, 性, 臨床 症状などに関係なく，出現するものは比較的多
量かつ高範囲にわたり出現している。一方全く 出現しないもの, あるいは出現してもごく少い ものもあり，個体差が大きいという印象をうけ る。即方対象の選び方により頻度に差ができる こともあり得ると考之られる。

2. 原線維変化と老人斑との関係：原線維変化 が老人斑に比へはるかに多いもの3例，老人斑 がはるかに多いもの 4 例となり，2つの変化の 数量的関連性はなく，むしろ解離傾向にある。 その出現部位も原線維変化が海馬域を好発部位 とするのに対し，老人斑ではこの領域はむしろ 好発部位ではなく, 分布においても解離してい ると言える。従って両者は別個の存在で，この $2 つ の$ 変化の産生の基底には異ったプロセスが 示唆される。このことは平野7, Dayan"), 金 ${ }^{13)}$, Raskin $^{21)}$ らの見解と一致する。一方森松17!は海 馬域の検索で顕著な量的相関は認めにくかった が，出現数を 3 段階に分け対応する例数の分布 を調べたところ両者の変化量の間に大まかな平 行関俰がみられ，これらの変化の生成の基盤に 老化過程を含めて何らかの共通の因子が存在す ることを示唆すると述べている。しかし海馬域 という限られた範囲のみでの検索であるという 点でその解釈にはかなりの限界があると思われる. 3. 年令との関係：原線維変化と加令との関係 を系統的に調へたた研究は少い，金 ${ }^{13)}$ は原線維変 化は50才代から急にその出現頻度を增し，70才 以上になるとほとんど全例に認められるとし， 森松17)の海馬領域での検索では，出現数を 0,1 $\sim 10,11 \sim 100,101$ 以上の 4 段階に分け, 痴呆 を考虑せず年令と出現数との関保をみると，原 線維変化における相関が最も顕著で老人斑がこ れに次ぎ，出現数11〜100および101以上のグル 一プが加令とともに増していると述べている。 正常老人を調べたTomlinson ${ }^{24)}$ も75才を境とし て原線維変化, 老人斑とも出現頻度が增す傾向 にあるが，更に症例の穔み重ねが必要であると している．同じく正常老人を検索したDayan ${ }^{4)}$ は60才以上では海馬域，前頭葉に両変化を示す 割合が增すが明らかな相関関係はないとしてい る。私の研究においては全例が70才以上であっ たことから原線維変化, 老人斑ともその出現量 と年令との間には相関はみられず，特に老人斑 
では個体差が大きかった。

4. 原線維変化, 老人斑と痴呆との関係: Day$\mathrm{an}^{42,5)}$ は檤血管障害等の痴呆の原因となるもの を除く長期に精神病院へ入院して老年痴呆と診 断された40例の症例と70例の正常老人との原線 維変化と老人斑の量的比較分析を右中前頭回と アンモン角の 2 部位で行った。それによると痴 呆群ではアンモン角に原線維変化が多量に出現 する傾向がみられるが，老人斑の出現数は非瘫 呆群と比較して有意の差はないとした，森松 ${ }^{17)}$ は海馬領域のみについて痴呆群と非痴呆群の間 の量的差を検討し、両変化の出現量は痴呆群に 有意に高いとした。また Blessed"1) らは生前の 知的生活能力と死後の皮質の各部における老人 斑の数との間には高い相関があるとした．私の 研究では痴呆症状を示した 7 例中脳軟化のない ものは 2 例のみで極めて少数であり，痴呆症状 が老年変化のみでなく脳軟化によることも十分 考之られるため痴呆と老年変化との関係を明ら かにすることはできなかった。

5. 脳幹における原線維変化：平野 ${ }^{81}$ は多数の Parkinson dementia complex の症例の脑幹の 原線維変化を系統的に検索した結果，ある神経 細胞はこの変化をおこしやすいことを明らかに した。一方石井 ${ }^{10}$ は老年知呆の患者 6 例の脳幹 での原線維変化を調べ，その好発部位は，N. dorsalis raphes, $N$. centralis superior 等であ $\eta$, 次いでN. reticularis tegmenti, 青斑核が好 発部位であるとした。石野11) は Alzheimer 病， 老年痴呆, 一般老人の脳幹での原線維変化の出 現頻度の比較を行い，その結論として老年痴呆 における分布，頻度については石井の結果とほ は一致したが, Alzheimer 病と比へてて老年痴呆 の方が出現頻度が低い傾向にあり，一般老人脳 では N. dorsalis raphes と青斑核にわずかに出 現したのみで稀であり，老年痴呆の例と比へてて 明らかな対比を示したとしている。私の検索で も14例中原線維変化を欠いていたものが5例で あり，出現するものでもその実数は極めて少な く，N. dorsalis raphes, 青斑核にわずかに出現 したのみで，石井や石野の Alzheimer 病，老年 痴呆の出現頻度と比較すると極めて少なく明ら かに对比をなすものと思われる．
私の研究での症例は精神分裂病の 1 例を除き 13例は全て老年期における精神障害や痴呆のた め正常なコミュニティーの中での活動的な生活 が不可能な人々であったが，これを臨床的に痴 呆のない正常老人について全脳にわたって検索 した Tomlinson ${ }^{24)} の$ 結果と比較してみると, 私 の結果の方が原線維変化の出現頻度と海馬領域 を除く側頭葉におけるこの変化の出現頻度が高 いことを除いて，次の点においてほぼ一致した ことは興味深い. 即ち原線維変化がアンモン角, 海馬回, 海馬旁回にほぼ限られ, 前頭葉, 頭頂 葉, 後頭葉にはほとんど見られなかった点であ る.つまり原線維変化がアンモン角, 海馬回, 海馬旁回の範囲に限局しているかぎり，それは 生理的な老年変化の過程とみてさしつかえない。 しかし原線維変化が前頭葉, 頭頂葉, 後頭葉に も多く出現するならばそれは生理的老年変化を 逸脱したものとみなせる。また原線維変化は脳 幹には稀にしか認められず，この部に多数の原 線維変化を認める Alzheimer 病, 老年痴呆とき わだった对比を示している。一方老人斑の分布 は全脳にわたるが, アミロイドよりなる芯をも たない小型の老人斑が多くを占め, 芯をもつ大 型で成熟したものは少なく，また海馬領域に比 較的少ないことは, Alzheimer 病, 老年痴呆の 出現椂式との差異である.

6 . 進行性核上麻㾝と老人脳における老年性変 化の相違：進行性核上麻㾇の大脳皮質における 原線維変化についての従来の報告は, 原線維変 化はほとんどないか, 存在するにしてもごく少 数であるというものであるが22,33,14),151,16),石野12) は2 例の進行性核上麻㾇の原線維変化の頻度を 大脳半球の Bodian 標本で検索し, 従来考之ら れていたより意外に多くの原線維変化が出現す ることを見い出し，その頻度はおそらく正常老 人脳より多いのではないかと指摘しているが, 对照例がなかったため結論としてはより慎重に ならざるを得なかった，今回，私は石野が検索 した 2 例の Bodian 標本を再び㭘索すると同時 に，老人脳14例を同じ方法で検索しこれを対照 例として比較を行った。その結果，大脳皮質の 原線維変化の出現量は対照老人脳と比べて明ら かに多く，特に前頭葉においてそれが顕著であ 
つた．前頭葉における原線維変化の出現頻度は 对照老人脳では極めて稀で前頭部には14例中 1 例 にただ1個の出現をみたのみであるが，進行性 核上麻㾝では 2 例ともかなりの数で出現してお ク, 老化という非特異的な変化から逸脱したも のであると言わさるる得ない．ただ海馬領域に おける頻度と形態は对照例と比較して特異的な 変化とは言い難い，一方大脳皮質における光顕 像について，平野8)は $\mathrm{H} \cdot \mathrm{E}$ 染色で原線維は $\mathrm{Al}$ zheimer 型の様にへマトキシリンで青く染まら ないと述べのの差異を指摘している，石野12)の 観察でも原線維変化の大部分は小型の神経細胞 に現われ，よく保たれた核をとりまく紐状の形 で存在し，原線維変化の過程はこれ以上には進 行しないで長く組織内にとどまるものと推測し ている。私の検索では大脳皮質や橋核における その形態は老年痴呆にみられるものと比へてて次 の相違点が明らかになった，即ち大脳皮質では 小型の神経細胞に多発し，大脳皮質や橋核では Bodian 染色で老人脳のものより濃く黒染し，原 楾維変化が比較的細く，原線維の少い紐状，網 目状，樹枝状の原線維変化からなり，核や細胞 体の形はよく保たれていることである。例えば 進行性核上麻瘦の前頭葉では老人脳よりもはる かにこの種の原線維変化が多く，しかも Bodian 染色で濃染し老人脳にみられる原線維変化とは 異なった上述の形悲のものがほとんどである。 一方老人斑は進行性核上麻㾇の 2 例には認めら れす，对照老人脳における高い出現頻度ときわ だった相違をみせている，進行性核上麻溥の原 線維変化は電顕上 straight tubules で構成され, Alzheimer 病，老年痴呆, Parkinson-dementia complex, 脳炎後パーキンソニズムなどの twisted tubules とは異なると言われて来たが201,222， ${ }^{23)}$, 朝長 ${ }^{25}$ )は進行性核上麻疩の原線維変化にも twisted tubles がみられるとしている.しかし進
行性核上麻㾴の大脳皮質における原線維変化の 電顕的検索はその出現頻度からみても至難であ り現在までない，今回の検索からみて，おそら く大脳皮質や橋核にみられる光顕上で特徵的な 形態を示す原線維変化は進行性核上麻㾝に特異 的なものである可能性が示唆される。

\section{結语}

1） 2 例の進行性核上麻㾝（62才と71才）と対 照例（70才以上の老人脳）14例について，大脳 皮質の老年性変化の頻度と形態を, 大脳半球切 片のBodian 標本について比較した。

2 ）対照とした老人脳14例の原線維変化の出現 頻度は $100 \%$ で, 好発部位は海馬回を中心とした 部位である．老人斑の出現頻度は $86 \%$ で，その 形態は小型で未熟なものが大多数で，各頭葉に 広範に分布し，海馬回には比較的少ない．また 老人斑の出現頻度には個体差が認められ, 原線 維変化と老人斑の数量的関連性はなく，むしろ 解離傾向にある. また原線維変化と老人斑の数 と年令との関係は認めなかった。

3 ）進行性核上麻疸の 2 例には老人斑を認めな かった。原線維変化の出現頻度は对照とした老 人脳に比へてて多い. また大脳皮質の第 2,3 層 の神経細胞や橋核の神経細胞に多発し，その大 多数は Bodian 染色で濃紺, 黒に濃染し, 原線 維が細く，紐状，網目状，樹枝状を呈し，核や 細胞体がよく保たれる点で，对照老人脳との間 に差異がみられる。しかし海馬領域では形態や 染色態度も对照群と同じものが多い。

\section{謝辟}

稿を終えるにあたり，御烈篤な御指導と御校閲を 賜った大月三郎教授に深く感謝申し上げます。また 終始御指導，御教示をいただいた石野博志博士に心 から感謝いたします。なお標本作製に御協力くださ つた絊田孃に厚く御礼申し上げます。 


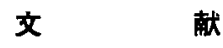

1. Blessed, G., Tomlinson, B.E., Roth, M.: The association between quantative measures of dementia and of senile change in the cerebral grey matter of elderly subjects. Br. J. Psychiatr. 114, 797-811, 1968.

2. Blumenthal, $H$. and Miller, C.: Motor nuclear involvement in progressive supranuclear palsy. Arch. Neurol. 20, 362-367, 1969.

3. David, N.J., Mackey, E.A. and Smith, J.L.: Further observation in progressive supranuclear palsy. Neurology (Minneap.) 18, 349-356, 1968.

4. Dayan, A.D.: Quantitative histological studies on the aged human brain, I. Senile plaques and neurofibrillary tangles in "normal" patients. Acta Neuropathol. 16, 85-94, 1970.

5. Dayan, A.D.: Quantitative histological studies on the aged human brain, II. Senile plaques and neurofibrillary tangles in senile dementia. Acta Neuropathol. 16, 95-102, 1970.

6. Gellerstedt, N.: Zur Kenntnis der Hirnveränderungen bei der normalen Altersinvolution. Upsala Läkareförn Förhandl 38, 193, 1932.

7. Hirano, A. and Zimmerman, H.M. : Alzheimer's neurofibrillary changes, Atopographic study. Arch. Neurol 7, 227-242, 1962.

8. 平野朝雄：神経病理を学ぶ人のために，医学書院，78，1976.

9. 猪瀬 正：老人脳の病理. 精神経誌, 57, 63-96, 1955.

10. Ishii, T: Distribution of Alzheimer's neurofibrillary changes in the brain stem and hypothalamus of senile dementia. Acta Neuropathol. (Berl) 6, 181-187, 1966.

11. Ishino, H. and Otsuki, S.: Frequency of Alzheimer's neurofibrillary tangles in the basal ganglia and brain-stem in Alzheimer's disease, Senile dementia and the aged. Folia Psychiatr. Neurol. Jpn. 29, 280 -287, 1975.

12. Ishino, H. and Otsuki, S.: Frequency of Alzheimer's neurofibrillary tangles in the cerebral cortex in Progressive supranuclear palsy (Subcortical argyrophilic dystrophy). J. Neurol. Sci. 28, 309-316, 1976.

13. 金 䗲洙：老人脳/研究. 福岡医誌, 35, 1167-1196, 1942.

14. 小林横雄, 飯島 真, 波多野道信, 赤井契一郎, 吉倉範光：Lafora 様封入体を認也た進行性核上麻疸 (Steele-Richardson-Olszewski 症候群) の 1 例. 神経進歩, 19, 384-395, 1975.

15. 万年 徹, 豊倉康夫, 塚越 広, 宮武 正, 毛利 昇, 横山 武：Progressive supranudear palsyの 1 剖 検例. 神経進歩, 16, 497-503, 1972.

16. 真野行生，渡辺英夫，永田康夫，西垣恵光：Progressive supranuclear palsy $の 1$ 例. 臨床神経, 14, 399-405, 1974.

17. 森松光紀：老年者の脳海馬領域の退行変化，その年秢，性，痴呆との関係. 日本老年医学会雑誌、12,30$39,1975$.

18. Müller, W.: Ergebnisse vergleichender pathologischanatomischer Untersuchungen des Gehirns unter besonderrer Berücksichtigung der Altersveränderungen. Arch. Psychiatr. Nervenkr 109, 147, 1939.

19. 仲村禎夫：老人脸の研究，アルツハイマ一原線維変化と老人斑の頻度について. 慶応医学, 50, 37-47, 1972.

20. Powell, H.C., London, G.W. and Lampert, P.W.: Neurofibrillary tangles in progressive supranuclear palsy. Electron microscopic observations. J. Neuropathol. Exp. Neurol. 33, 98-106, 1974.

21. Raskin, N. and Ehrenberg, R.: Senescence, Senility, and Alzheimer disease. J. Psychiatr. 113, 133$137,1956$.

22. Roy, S., Datta, C.K., Hirano, A., Ghatak, N.R. and Zimmerman, H.: Electron microscopic study of neurofibrillary tangles in Steele-Richardson-Olszewski syndrome. Acta Neuropathol. (Berl) 29, 175-179, 
1974.

23. Tellez-Nagel, I. and Wisniewski, H.M.: Ultrastructure of neurofibrillary tangles in Steele-RichardsonOlszewski syndrome. Arch. Neurol. 29, 324-327, 1973.

24. Tomlinson, B.E., G. Blessed, and M. Roth.: Observations on the Brains of Non-Demented Old People. J. Neurol. Sci. $7,331-356,1968$.

25. Tomonaga, M.: Ultrastructure of neurofibrillary tangles in progressive supranuclear palsy: Acta Neuropathol. (Berl.) 37, 177-181, 1977.

26. 渡辺道雄, 野村章恒：老人脳の病理解剖学的調查. 浴風園紀要, 第 9 輯, 1932. 


\author{
Comparison of senile changes in the cerebral cortex \\ due to progressive supranuclear palsy and senile brains \\ Ken SASAKI \\ Department of Neuropsychiatry, Okayama University Medical School
}

(Director : Prof. S. Otsuki)

1) The frequency and microscopic morphology of senile changes are compared, in frontalcut Bodian preparations, in two cases of progressive supranuclear palsy (ages 62 and 71) and 14 control senile brains (between the ages of 70 and 91).

2) Neurofibrillary tangles were found in all the control brains with a predilection for hippocampal areas. Senile plaques were found in 86 per cent of all the control cases. Most were small and primitive, with great individual variations in frequency. The numbers of neurofibrillary tangles and of senile plaques did not correlate, but rather were dissociated. No relation was found between the number of tangles and/or senile plaques and the ages of the control patients.

3) Two cases of progressive supranuclear palsy showed no senile plaques. Neurofibrillary tangles were more numerous than in the control senile cases. Tangles were found in the outer and middle layers of the cerebral cortex and in the pontine basis. In Bodian preparations, most were black, presenting fine tangles with string and mesh forms. The nucleus and cell plasma were preserved in contrast to senile brains. But in the hippocampal areas, differences in form were not observed between tangles of progressive supranuclear palsy and control brains. 